IJ§ER

ISSN: $2149-5939$
International Journal of Social Sciences and Education Research

Online, https://dergipark.org.tr/tr/pub/ijsser

Volume: 6(4), 2020

\title{
The relationship between levels of personal economic returns and educa- tion indicators ${ }^{1}$
}

\author{
M. Bachirou Djibril Issoufou ${ }^{2}$ and Esen Altunay ${ }^{3}$
}

Received date: 28 / 09 / 2020

Accepted date: $29 / 11 / 2020$

\begin{abstract}
This research aimed to examine the relationship between the educational indicators and the level of personal economic returns for Niger, Turkey, and France. In this study, a systematic review design, in which we compared three countries' data and examined the relationship between education indicators and personal economic returns level. There was a very strong correlation between literacy population, mean years of schooling, and educational expenditure, and a modest relationship between population growth rate and the level of personal economic returns, according to the findings of the study. The first predictor was the mean years of schooling and the second predictor was the educational expenditure. The relationship between them and the level of personal economic returns was positive and significant
\end{abstract}

Keywords: Level of personal economic returns, educational expenditure, mean years of schooling, literacy.

\section{Introduction}

Evaluation of the younger part of the population should be a top priority in each state's policy. In particular, it is very important to use human capital properly to create an active, self-improving, and open-minded learning profile on the targeted labor market and to raise the level of development, and this accumulation needs to be properly planned (Avc1, 2015). The World Bank divides countries into three groups as lowest-income, middle-income, and top-income countries, according to purchasing power parity and per capita income. Countries in the lowest income group are considered to be "underdeveloped" as the world's poorest countries, middle-income countries are" developing", and in the highest income group are" developed" countries (Çetin, 2014). In this direction, all countries strive to increase their citizens' incomes and to increase the country's welfare, and to try to improve their economies. Each nation, however, has distinct resources and opportunities. They are therefore attempting, in the most productive way, to use and grow their capital. Manpower improvement is one of these strategies. Within its capacities, each nation makes investments in education systems.

The main purpose of education is to provide various benefits to the child and the community. While education contributes to the development of a strong society in social terms, it also contributes to the creation of a developed country in economic terms. Education contributes both directly and indirectly to the economy. Education's direct contribution is to increase the manpower's output and the efficiency of production through improving human resources. The indirect contribution is that it primarily affects the behavior, opinions, and values of people, which then

\footnotetext{
${ }^{1}$ This article was developed and extended based on a thesis titled " The Relationship Between Personal Levels of Economic Returns and Education Indicators: The Case of Niger, Turkey, and France " presented in 2017

${ }^{2}$ Master Teacher, Qt Banifandou2/ Niamey, Niger besmamde@gmail.com; maman3656@gmail.com

${ }^{3}$ Corresponding Author, Ph.D. Assoc. Prof. at Educational Administration, Planning and Economy, Ege University, Bornova Izmir, Turkey, ORCID:0000-0001-8200-8871 esenaltunay@yahoo.com; esen.altunay@ege.edu.tr
} 
Djibril Issoufou, M.B., Altunay, E. (2020). The relationship between levels of personal economic returns and education indicators. International Journal of Social Sciences and Education Research, 6(4), 556-568.

enables the adoption of innovations and the use of modern methods, as well as helping the development of the country (Karip, 2002). However, it is noted that underdeveloped, emerging, and developed countries are not able to benefit comparably from education systems. For this reason, the relationship between education indicators according to the development levels of countries and the gross national product per capita stands out as an issue that needs to be researched.

\section{Literature review}

Trained human resource constitutes the most significant input to any country's economy. Education increases the productivity of the workforce, people's knowledge of new processes, technology, and the product, which is the innovative capacity, and allows information to be disseminated, thereby ensuring economic development and growth. The developed countries need more educated people to maintain this growth, and the developing and underdeveloped countries also need efficient human capital (Büyükaslan, 1995). According to the theory of human capital, a linear relationship exists between the number of goods and services produced at a given time, the individual's income, and the human resources investment (Schultz, 1992). As the level of investment for human beings increases, so do both national and individual income (Öztürk, 2005). Accordingly, human characteristics vary from one another, and if investments are made in all facets of the individuals, the individuals will develop as socially complete. Therefore, the fully qualified individual's production and income will be high. Social investment is needed for the full development of the child (Kurul, 2012). In this context, investment for human capital may be useful, especially in underdeveloped and developing countries. Also, it is observed that labor productivity tends to increase in countries where the level of education is high and revenue equity has reached the desired level. Adam Curle (1964) for 50 nations in 1954-1959 and Bennet (1967) for 69 countries reported that the knowledge and skills acquired at the secondary school level contributed to GNP and economic growth. Economists such as Bowman (1966), Schultz (1961, 1971: cited 2010), and Becker (1975) have shown that, on the one hand, trained individuals increase their incomes and, on the other hand, contribute externally to society. As this information indicates, investments in educational institutions provide increased long-term returns and bring the countries to advanced levels of development (Taş, 2007).

"Individual and social educational returns" change depending on the level of economic growth in different countries. In particular, the educational return of the different countries differs individually and socially depending on the expenditure for the education system and the priority given to education. Education expenditure is high in developed countries, whereas in developing and underdeveloped countries this expenditure is low (Gövdeli, 2016; Idrees \& Siddiqi, 2013). For this reason, educational return rates in countries with high economic growth are higher, both personally and socially compared to the countries with low economic growth levels. On the other hand, the levels of educational returns and educational expenditure affect economic growth. In other words, educational expenditure increases labor productivity by contributing to the accumulation of human capital and has a positive impact on economic growth (Kızılkaya \& Koçak, 2014; Blankenau \& Simpson, 2004).

Determining how much individuals and society benefit to explain the economic return of education is expressed in personal and social return rates. Considering the costs and benefits per individual's earnings directly because of the individual's level of education is known as a personal rate of return. It is also a public rate of return that takes into account all direct personal and public costs and benefits to the Community (Gölpek, 2012; Woodhall, 1994). Return rates for all levels of education are positive in many countries; rates of return for primary and secondary education

Copyright (C) by International Journal of Social Sciences and Education Research ISSN: 2149-5939 
Djibril Issoufou, M.B., Altunay, E. (2020). The relationship between levels of personal economic returns and education indicators. International Journal of Social Sciences and Education Research, 6(4), 556-568.

are higher than those for university education; rates of return in developing countries are higher than in developed countries (Psacharopoulos \& Patrinos, 2004). Looking at the social impact of education around the world, social return rates in less developed countries have reached a higher level (Psacharopoulos, 1985). For this reason, the relationship between education and personal return rate has been studied for a long time.

Looking at the literature on the rate of return of education we can see some research, such as Mincer (1974), Boarini and Strauss (2007), Gomez-Castellanos and Psacharopoulos (1990), Kugler and Psacharopoulos (1989), Psacharopoulos and Chu Ng (1994), Tansel (1994, 2008), Tansel and Daoud (2014), Çalışkan (2007), and Sarı (2002). According to Psacharopoulos and Patrinos (2004), the average return of education is dropping as the level of economic growth and employment increases. In a study conducted by Stevens and Weale (2004), there was a positive relationship between the level of primary school and the GNP per capita. Additionally, many worldwide surveys show that the level of education in terms of contribution to the economy is very high. In developing countries, the rate of social benefit is $24 \%$ in primary school, $15 \%$ in secondary school, and 3\% in higher education, according to World Bank figures (Doğrul, 2008). To assess the contribution of income per capita on the GNP, countries collected education indices and used them as a data source. These indicators are schooling rates according to educational levels of nations, literacy rate, duration of education completed, number of students per classroom and teacher, gender rates, public and private expenditures per student, the rates of those who attend vocational and technical education, etc. (Polat, 2010). Accordingly, the literacy rate, the period of completed schooling, the spending on education, and the measures of population growth rate are used in this research to address the level of per capita education and the level of education per person.

In the related literature, research by educational scientists on the economy of education is limited (Altunay, 2017; Ulusoy, 2013; Wigley \& Akkoyunlu 2011). Recent research is related to econometrics, educational economics, economics-administrative sciences, the labor market, and is often seen as attempting to explain the cases of employment, income; and the distribution of education and income. In this sense, as underdeveloped, developing, and developed countries, comparison and study of Niger, Turkey, and France's educational indicators and personal gain will contribute to the relevant literature. The rationale for selecting comparative data from Niger, Turkey, and France is related to the different rates of personal return between those countries. Additionally, these countries are grouped at different levels when compared to one another. For example, France is classified as a developed country, Turkey is classified as a developing country and Niger is classified as an underdeveloped country in terms of economic growth and the rate of development. Hence, a comparison of these countries in terms of personal economic return can provide important findings. At the same time, with regards to qualitative and quantitative structure, Niger, Turkey, and France are different. For example, the educational indicators (such as educational levels, mean years of schooling, literacy, girls' schooling rates) are the lowest in Niger. However, countries like Turkey and France are closer to each other based on these educational indicators. Finally, we can say that in the literature, the majority of education return research was carried out among countries of a similar standing, in particular between two developing countries or between two developed countries. Though there are limitations to the ability to generalize findings from any one particular study to other situations, this topic of study was important. It was initiated to help advocate for the development of a focused policy that better establishes and monitors the relationship between individual and social benefits and education practices. This paper has a twofold purpose. First, we plan to demonstrate the relationship between

Copyright (C) by International Journal of Social Sciences and Education Research ISSN: 2149-5939 
Djibril Issoufou, M.B., Altunay, E. (2020). The relationship between levels of personal economic returns and education indicators. International Journal of Social Sciences and Education Research, 6(4), 556-568.

educational indicators (literacy rate, population growth rate, educational expenditure, and mean years of schooling) and rate of personal economic return (GNP per capita) according to the indices of growth. This includes a focus on the questionable educational indicators. And secondly, we are going to use these insights to draw attention to the contradictory spaces of the various educational systems and the indices of Niger, Turkey, and France for development (As underdeveloped, developing, and developed countries respectively). We have searched for the answers to the following questions within this overall aim:

1. How are Niger, Turkey; and France's educational indicators distributed according to the GNP?

2. Is there a meaningful relationship between Niger, Turkey; and France's educational indicators and GNP?

3. Do the educational indicators of Niger, Turkey; and France predict significantly the GNP per capita?

\section{Method}

In this study, a systematic review design, in which the data of three countries were compared and the relationship between education indicators and personal economical returns level is examined. The study is focused on the secondary data from the some reports and researchs conducted previously. Secondary data analysis is a relatively under-used technique in Education and in the social sciences more widely. Document analysis is a systematic procedure for reviewing or evaluating documents-both printed and electronic (computer-based and Internet-transmitted) material (Bowen, 2009).

\subsection{Sample}

The study population consisted of data from the 15-64 age group from Niger, Turkey; and France. The study sample was the 1996-2015 World Bank, OECD, and UNESCO statistical data which covers the 15-64 age group.

\subsection{Data collection tool}

The data for this research was collected using the document-scanning technique. Document analysis is the method of reviewing some papers that the researcher claims are relevant to the topic of the study (Hodder, 2002). The study material used in this paper was generated through website statistics compiled between 1996 and 2015 by the various organizations. A form for collecting research data has been prepared. The following items were used in the form to collect data for the research:

- Rate of personal economic returns (GNP per capita);

- Educational indicators (literacy rate, population growth rate, educational expenditure, and mean years of schooling).

In this research, to ensure reliability in the educational indicators (educational expenditure, mean years of schooling, literacy rate, GNP per capita population growth rate (15-64), the educational data was taken from the International's official websites. The related websites are as follows: World Bank, OECD, UIS-UNESCO, Barro-Lee (1993), UNDP to confirm the data, we surveyed the statistics websites of Niger, Turkey, and France; INS, TUIK, and INSEE.

\subsection{Analysis of data}

The problem of endogeneity bias may arise when estimating the economic returns on education using the Mincerian wage regression model (Haider Bhatti, Bourdon, and Aslam 2013). In Copyright (C) by International Journal of Social Sciences and Education Research ISSN: 2149-5939 
Djibril Issoufou, M.B., Altunay, E. (2020). The relationship between levels of personal economic returns and education indicators. International Journal of Social Sciences and Education Research, 6(4), 556-568.

the study, the researchers transferred the data obtained from data collection tools to the computer, and statistical processing was performed with the Statistical Package for the Social Sciences (SPSS). Different analytical methods for the data analysis process were employed at each point of the research.

Firstly, we used percentage, frequency, and means to see the distribution of independent variables (population growth rate, level of literacy, mean years of schooling and educational expenditure) and dependent variables (GNP per person). Then, Pearson's Moments Multiplication Correlation Coefficient analysis was calculated to see the correlation of variables between them. The "stepwise regression" analysis method was used to determine whether GNP per capita was predicted by the independent variables such as the educational indicators (population growth rate, literacy level, means years of schooling and educational expenditure). In the stepwise regression analysis, the order of entry of independent variables into equality is determined by statistical measures. Each argument is assessed according to what is added to the equation in terms of its entry order (Tabachnick \& Fidell, 2007). All statistical definitions were tested at the level of significance $\mathrm{p}<0.5$ in the study.

\section{Findings}

Sub-problems discussed in this part of the research were provided with country-based data and a comparison model. The results are expressed in Table 1 and Table 2 according to the first subproblem of this analysis.

Table 1. Distribution of educational indicators (1)

\begin{tabular}{cccccccccc}
\hline Years & \multicolumn{3}{c}{ GNP per capita } & \multicolumn{3}{c}{ population growth } & \multicolumn{2}{c}{ mean years of schooling } \\
\cline { 2 - 9 } & Niger & Turkey & France & Niger & Turkey & France & Niger & Turkey & France \\
\cline { 3 - 9 } 1996 & 588,29 & 5824,36 & 21288,29 & & & & 1,30 & 5,88 & 9,36 \\
1997 & 593,00 & 6283,88 & 22220,02 & 4,70 & & $-0,20$ & 1,30 & 5,88 & 9,36 \\
1998 & 638,20 & 8718,84 & 23321,09 & 4,68 & $-0,12$ & 0,54 & 1,30 & 5,88 & 9,36 \\
1999 & 621,14 & 8311,06 & 24249,71 & 4,50 & 2,54 & 1,09 & 1,30 & 5,88 & 9,36 \\
2000 & 603,82 & 9320,91 & 25972,19 & 4,68 & 2,10 & 0,67 & 1,43 & 6,37 & 10,22 \\
2001 & 637,72 & 8749,15 & 27427,59 & 3,85 & $-3,49$ & 0,25 & 1,43 & 6,37 & 10,22 \\
2002 & 642,98 & 8784,44 & 28503,56 & 4,03 & 1,67 & 1,00 & 1,43 & 6,37 & 10,22 \\
2003 & 665,71 & 8915,65 & 28093,40 & 3,80 & 1,47 & 2,27 & 1,43 & 6,37 & 10,22 \\
2004 & 659,98 & 10218,93 & 29028,18 & 3,86 & $-0,67$ & 0,47 & 1,43 & 6,37 & 10,22 \\
2005 & 686,03 & 11512,46 & 30375,51 & 3,75 & $-0,19$ & 1,19 & 1,62 & 6,86 & 10,86 \\
2006 & 720,10 & 12897,00 & 32291,00 & 3,41 & 2,10 & 0,53 & 1,30 & 6,10 & 10,60 \\
2007 & 735,40 & 13895,00 & 34061,00 & 3,36 & 1,37 & 0,80 & 1,30 & 6,20 & 10,70 \\
2008 & 791,30 & 15021,00 & 35170,00 & 3,49 & 1,69 & 0,73 & 1,40 & 6,60 & 10,80 \\
2009 & 762,00 & 14491,00 & 34825,00 & 3,76 & 2,99 & 0,87 & 1,40 & 7,20 & 10,90 \\
2010 & 804,10 & 16012,00 & 35921,00 & 3,73 & 4,17 & 0,50 & 1,40 & 7,40 & 11,00 \\
2011 & 807,20 & 17692,00 & 37353,00 & 3,67 & 3,84 & 0,10 & 1,40 & 7,60 & 11,00 \\
2012 & 882,20 & 18437,00 & 37499,00 & 3,82 & 3,67 & 0,60 & 1,40 & 7,60 & 11,10 \\
2013 & 900,20 & 19156,00 & 39236,00 & 3,91 & 1,34 & 0,05 & 1,40 & 7,60 & 11,30 \\
2014 & 937,70 & 19610,00 & 39357,00 & 3,95 & 1,53 & 0,08 & 1,40 & 7,60 & 11,40 \\
2015 & & 20396,00 & 40170,00 & & 1,54 & & & 7,60 & 11,40 \\
Means & 719,84 & 12712,3 & 31318,12 & 3,94 & 1,5 & 0,64 & 1,3 & 6,7 & 10,5 \\
\hline
\end{tabular}

The distribution of educational indicators (population growth rate, rates of literacy, mean years of schooling, and educational expenditure) of Niger, Turkey; and France was measured according to the personal economic return rate (GNP per capita). The literacy rate, mean years of schooling, and educational expenditure showed a linear increase with GNP per capita but population growth is inversely proportional to GNP per capita. The rates of return to different human capital factors 
Djibril Issoufou, M.B., Altunay, E. (2020). The relationship between levels of personal economic returns and education indicators. International Journal of Social Sciences and Education Research, 6(4), 556-568.

can help individuals make decisions regarding their investment in education, based on their possible future earnings.

Table 2. Distribution of educational indicators (2)

\begin{tabular}{|c|c|c|c|c|c|c|}
\hline \multirow[t]{2}{*}{ Years } & \multicolumn{3}{|c|}{ Educational expenditure } & \multicolumn{3}{|c|}{ Literacy rate } \\
\hline & Niger & Turkey & France & Niger & Turkey & France \\
\hline 1996 & 48151459,85 & 110085940,17 & & 13,60 & 82,30 & 99,00 \\
\hline 1997 & 45343065,70 & 217975641,02 & 105600000000,00 & 13,00 & 85,30 & 99,00 \\
\hline 1998 & 45687956,20 & 531242735,04 & 116040000000,00 & 13,60 & 85,90 & 99,00 \\
\hline 1999 & 47000000,00 & 911029059,82 & 114480000000,00 & 15,30 & 86,30 & 99,00 \\
\hline 2000 & 48083941,60 & 1431764957,26 & 117840000000,00 & 16,00 & 86,40 & 99,00 \\
\hline 2001 & 43065693,43 & 1729190170,94 & 120840000000,00 & 14,38 & 86,30 & 99,00 \\
\hline 2002 & 43065693,43 & 3188457692,30 & 124320000000,00 & 15,30 & 87,50 & 99,00 \\
\hline 2003 & 63868613,13 & 4350426068,40 & 133560000000,00 & 17,60 & 88,30 & 99,00 \\
\hline 2004 & 88321167,90 & 5493439752,13 & 139560000000,00 & 28,70 & 87,40 & 99,02 \\
\hline 2005 & 102189781,02 & 6359939743,60 & 141480000000,00 & 28,70 & 88,20 & 99,00 \\
\hline 2006 & 108211678,83 & 7080403846,15 & 145680000000,00 & 28,00 & 88,10 & 99,00 \\
\hline 2007 & 125912408,75 & 9126339316,23 & 150360000000,00 & 28,66 & 88,70 & 99,00 \\
\hline 2008 & 158364160,60 & 9792976495,72 & 155640000000,00 & 28,70 & 91,78 & 99,00 \\
\hline 2009 & 179379562,04 & 11916109401,70 & 158520000000,00 & 28,70 & 90,80 & 99,00 \\
\hline 2010 & 171214565,90 & 12067270085,50 & 161760000000,00 & 15,00 & 92,70 & 99,00 \\
\hline 2011 & 183704379,56 & 14577847435,90 & 164880000000,00 & 28,70 & 94,10 & 99,00 \\
\hline 2012 & 230437956,20 & 16739050854,70 & 167280000000,00 & 29,70 & 95,78 & 99,00 \\
\hline 2013 & 202554744,00 & 20297594017,09 & 173760000000,00 & 30,00 & 95,74 & 99,00 \\
\hline 2014 & 238623466,67 & 23805474358,97 & 175200000000,00 & 30,00 & 95,44 & 99,00 \\
\hline 2015 & 501651098,09 & 26601709401,70 & 177360000000,00 & 31,00 & 95,69 & 99,00 \\
\hline Means & 133741569,9 & 8816416349,71 & 144429473684,2 & 22,7 & 89,64 & 99,00 \\
\hline
\end{tabular}

The second sub-problem is "Is there a meaningful relationship between Niger, Turkey, and France's educational indicators and GNP?" We measured the correlation coefficient of Pearson Moments. The results of the analysis are shown in Table 3.

Table 3. Correlation analysis results between educational indicators and GNP

\begin{tabular}{lccccc}
\hline Variables & $\begin{array}{c}\text { GNP per cap- } \\
\text { ita }\end{array}$ & Literacy & $\begin{array}{c}\text { Educational } \\
\text { expenditure }\end{array}$ & $\begin{array}{c}\text { Mean years of } \\
\text { schooling }\end{array}$ & $\begin{array}{c}\text { Population } \\
\text { growth rate }\end{array}$ \\
\hline GNP per capita & 1 & $0.815^{* *}$ & $0,935^{* *}$ & $0.957^{* *}$ & $-0.659^{* *}$ \\
Literacy & & 1 & $0,616^{* *}$ & $0.937^{* *}$ & $-0.768^{* *}$ \\
Educational expenditure & & 1 & $0.840^{* *}$ & $-0.567^{* *}$ \\
Mean years of schooling & & & & 1 & $-0.750^{* *}$ \\
Population growth rate & & & & & 1 \\
\hline$* * \mathrm{P}<0,01$ & & &
\end{tabular}

While analyzing the relationship between the variables of educational indicators, as shown in Table 3, the highest correlation coefficient $(r=0.937, p<0.01)$ was measured between literacy and the mean years of schooling.

It was observed that there was a high level, positive and significant relationship between GNP and literacy $(\mathrm{r}=0.815, \mathrm{p}<0.01)$. There was a very high level, positive and significant relationship between GNP and educational expenditure $(r=0.935, \mathrm{p}<0.01)$. There was a very high level of positive and significant relationship with the mean years of schooling and GNP $(r=0.957, p$ $<0.01$ ). As the last variable, there was a moderate, significant and negative relationship between population growth rate and GNP $(\mathrm{r}=-0,659, \mathrm{p}<0.01)$. In general, it was observed that as the literacy rate, educational expenditure, and mean years of schooling increase, unlike the population growth rate decreases. As a result, the GNP increases. 
Djibril Issoufou, M.B., Altunay, E. (2020). The relationship between levels of personal economic returns and education indicators. International Journal of Social Sciences and Education Research, 6(4), 556-568.

A stepwise regression analysis was applied using the values of the educational indicators for the third sub-problems of this research (Table 4). The independent variables included in the regression analysis were the following: literacy rate, mean years of schooling, educational expenditure, and rate of population growth.

Table 4. Stepwise regression results relating to the predicted the GNP Per Capita

\begin{tabular}{|c|c|c|c|c|c|c|c|c|c|c|}
\hline & Variables & $\mathrm{B}$ & $\mathrm{SH}$ & $\mathrm{B}$ & $\mathrm{T}$ & Sig. & $\mathrm{R}$ & $\mathrm{R}^{2}$ & $\mathrm{R}^{2}{ }_{\text {exchange }}$ & $\mathrm{F}$ \\
\hline \multirow[t]{2}{*}{ Step 1} & Constant & $-5,918.73$ & 986.18 & & -6.002 & 0,000 & & & & \\
\hline & $\begin{array}{l}\text { Mean Years of } \\
\text { Schooling }\end{array}$ & 3368.539 & 136.137 & .960 & 24.744 & 0,000 & .960 & .922 & .922 & 612.250 \\
\hline \multirow{3}{*}{$\begin{array}{c}\text { STEP } \\
2\end{array}$} & Constant & 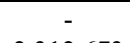 & 633.97 & & -3.648 & 0,000 & & & & \\
\hline & the mean years & $\begin{array}{c}2,312.673 \\
2084.17\end{array}$ & 138.78 & .594 & 15.018 & 0,000 & .988 & .977 & 0,055 & 1072.031 \\
\hline & $\begin{array}{l}\text { Educational Ex- } \\
\text { penditure }\end{array}$ & $8.624 \mathrm{~A}-8$ & 0,000 & .435 & 10,993 & 0,000 & & & & \\
\hline \multirow[t]{4}{*}{$\begin{array}{c}\text { STEP } \\
3\end{array}$} & Constant & $\begin{array}{c}- \\
4,922.266\end{array}$ & 1202.348 & & -4.094 & 0,000 & & & & \\
\hline & $\begin{array}{l}\text { the mean years } \\
\text { of Schooling }\end{array}$ & 2341.397 & 167.201 & .667 & 14.003 & 0,000 & 0,990 & .979 & 0,003 & 791.009 \\
\hline & $\begin{array}{l}\text { Educational Ex- } \\
\text { penditure }\end{array}$ & $8.282 \mathrm{~A}-8$ & 0,000 & .418 & 10.909 & 0,000 & & & & \\
\hline & $\begin{array}{l}\text { Population } \\
\text { growth rate }\end{array}$ & 583.647 & 232.604 & 0,078 & 2,509 & 0,015 & & & & \\
\hline
\end{tabular}

As can be seen in Table 4, the variable of "mean years of schooling" was analyzed during the first phase of the stepwise regression analysis. The "mean years of schooling" variable alone explained about 92 percent of GNP $\left(R=0.960, R^{2}=0.922, p=0.001\right)$. The bilateral correlation between the "mean years of schooling" and the GNP per capita variables were found to be positive and significant $(\mathrm{r}=0.957)$.

The variable "educational expenditure" was introduced into the model along with the variable "mean years of schooling" in the second step of the stepwise regression study. The variable "educational expenditure" added 5.5 per cent to the variance explanation, raising the variance stated in the GNP statistic to 98 per cent $\left(\mathrm{R}^{2}\right.$ change $\left.=0.055, \mathrm{R}=0.988, \mathrm{R}^{2}=0.977\right)$. The other variables remained constant, as we found for the "mean years of schooling" variable. The bilateral correlation between the variable "educational expenditure" and the GNP per capita was found to be positive and significant $(\mathrm{r}=0.935)$. It has been observed that in addition to the "mean years of schooling" variable, the "educational expenditure" variable explains the GNP to a significant extent.

The variable "population growth rate" was added to the variables "mean years of schooling" and "educational expenditure" in the third stage of the stepwise regression analysis. The population growth rate contributed 0.3 percent to explain the total variance, and the magnitude of GNP per capita increased the explained variance to 98 percent $\left(\mathrm{R}^{2}\right.$ change $=0.003, \mathrm{R}=0.990, \mathrm{R}^{2}=$ 0.979). It was found that the bilateral correlation between "population growth rate" and GNP per capita was negative and significant $(r=-0,659)$.

In conclusion, the stepwise regression analysis which was applied to estimate GNP per capita, has been completed in three steps. In the regression equation, we found that the "mean of years schooling", "Educational Expenditure", and "Population Growth Rate" variables were predictive of the magnitude of GNP per capita and these three variables explained about 98 percent of the total variance. When the variance values were explained separately in the magnitude of GNP by each of the three variables in the regression model, it was seen that 92 percent of the total variance in the size of GNP is explained independently by "the mean years of schooling". Among the educational indicators, "the mean years of schooling" has the biggest impact on GNP. This 
Djibril Issoufou, M.B., Altunay, E. (2020). The relationship between levels of personal economic returns and education indicators. International Journal of Social Sciences and Education Research, 6(4), 556-568.

variance is 5.5 percent for the "educational expenditure" variable and 0.03 percent for "the population growth rate".

\section{Discussion}

We found that the average GNP per capita was at the highest rate for France, whereas the lowest average was for Niger. The highest rate of "population growth" in the country with the lowest GNP per capita was calculated, whereas the lowest rate of population growth in the country with the highest GNP per capita was estimated. Population growth, according to Dao (2012), is inversely proportional to the effect of GNP per capita growth everywhere. Developing countries in Sub-Saharan Africa and South Asia, according to Kandir (2013), are also countries where poverty is common as well as rapid population growth. On the other hand, the highest literacy rate was in France but the lowest was in Niger. It shows a rise in a linear and positive direction when comparing the data of these three countries. In addition, these results were also endorsed by the research findings of Desai (2012) and Rahman (2011). Accordingly, a positive relationship between the literacy level and GNP was noticed in India and some other Asian countries. Psacharopoulos and Woodhall (1985) defined a linear link between national income and literacy.

Another result of our study was that there was a longitudinal and positive change between the "mean years of schooling" and the GNP for France, Niger; and Turkey. According to Ergen (1999), an increase over the average duration of schooling of the labor force in Turkey, is causing increases in the GNP. According to Gylfason and Zoega (2003), raising the level of education and improving the quality directly increases national income. According to the OECD and UNDP estimates, a linear relationship exists between the rise in per capita national income and student achievement (Aydın 2015). In other words, it is claimed that education makes a positive contribution to economic growth. As a matter of fact, the contributions of the education year or education levels to the income of the individuals differ according to the level of development of the countries. While education levels are high in developed and developing countries, underdeveloped countries still have the lowest level of education. Moreover, it was discovered that the expenditure in education was spent mostly in France, and the least in Niger. Accordingly, the three countries ' education expenditure shows a steady rise, with a linear and positive change between education expenditure and GNP per capita. According to Idress and Siddiqi (2013), the effect of educational expenditure on economic growth in developing countries is greater than that of developed countries. Policymakers also need to allocate resources so that they prevent or eradicate discrimination in economic incentives based on geography, ethnicity, gender, or age (Haider Bhatti, Bourdon, \& Aslam, 2013).

As a consequence, the rapid population growth contributed to the depletion of the countries ' natural resources, the reduction of savings and investments, and the negative impact on economic development. In a society with a high literacy rate, GNP per capita may be high due to living standards, capacity of the workforce, and the efficient use of natural resources in the country. Moreover, the low literacy rates in underdeveloped countries may be due to the lack of access to students in rural areas, the discrimination of women and the right to access education. This can lead to low GNP per capita for people who are unable to engage within an economically skilled work force. Like other underdeveloped countries, Niger has a low enrollment rate which affects the average number of years of the completed duration of education. In addition, because the introduction of compulsory education in a country is not effectively controlled, mean years of schooling will result in low income (return rate). The reason why the mean years of schooling in Turkey and France has reached a significant level might result from all of the school-age

Copyright (C) by International Journal of Social Sciences and Education Research ISSN: 2149-5939 
Djibril Issoufou, M.B., Altunay, E. (2020). The relationship between levels of personal economic returns and education indicators. International Journal of Social Sciences and Education Research, 6(4), 556-568.

population enrolling in school. Nonetheless, Turkey's mean years of schooling hasn't exceeded the duration of compulsory education. On the other hand, with the average duration of education completed, the linear and positive increase of GNP per capita can lead to an increase in society's educational level, high earnings and contribute to the country's national revenue. Apart from these results, it can be said that expenditure on education by developing the human capital resource increases the productivity of individuals and the GNP per capita.

There has been a significant relationship between the indicators of education and GNP per capita for France, Turkey and Niger. We found the highest relationship between the mean years of schooling, and GNP per capita, and at the lowest relationship between population growth rate and GNP per capita, among the indicators of education. Bowman and Anderson's (1961) research found a strong relationship between the literacy rate and economic growth. Harbison and Mayers (1964) found a high relation between education level and personal income. We found a strong and positive relationship in the Geyikdağı study (1976), which looked at the connection between education expenditure and GNP. Telatar and Terzi (2010) have identified a positive relationship between income per capita and higher education. There's a negative relationship between population growth rate and GNP per capita, according to Sars1lmaz (2003) and Kelley (1988). Nevertheless, in Turkey, Güneş (2005) found a positive link between per capita national GNP and population growth rate. We can say the mean years of schooling affects the level of economic return. These results support the theory of human capital. As the education level of the individual rises, the elimination and queuing hypothesis will explain the finding of employment and the acquisition of high income.

All in all, GNP per capita was predicted significantly through the mean years of schooling, educational expenditure, and population growth rates, while GNP per capita was not predicted significantly by literacy variable. When France, Turkey; and Niger's mean years of schooling and educational expenditure increase, GNP per capita rises. In the study of Geyikdağ (1976), it was found that as education expenditure rises in Turkey, GNP per capita increases. According to the survey findings and the findings of this research, education expenditure and mean years of schooling make a significant contribution to the size of GNP per capita. For this reason, the longer the mean years of schooling increases, the more resources are allocated to education, which can lead to increased economic returns. According to the theory of human capital, this outcome may be linked to the low literacy rate in Turkey and orderly development. On the other hand, Sellar and Lingard (2013) claim that in order to understand the rise of education in the developed countries, we must appreciate how their adoption of human capital theory influenced its work. Sellar and Lingard state that the growing role of education in the developed countries, globally has 'occurred in the context of the simultaneous 'economization' of education policy and 'educationising' of economic policy. The OECD now conceptualizes education and skills as central to the economic policies of knowledge-based economies, for example, PISA has become a measure of national economic potential.

As a result, the contribution of this study to literature and practice can be summarized as follows. Niger, France, and Turkey, according to the development index, we attempted to examine the relationship between the rate of personal economic return (GNP per capita) and education indicators. The theoretical infrastructure of personal income levels varies and is very comprehensive in the literature. Thus, we have determined that there is a need to examine the distribution of education indicators of three countries with different development indexes for personal GNPs, the relationship between education indicators and GNP, and the level of education indicators 
Djibril Issoufou, M.B., Altunay, E. (2020). The relationship between levels of personal economic returns and education indicators. International Journal of Social Sciences and Education Research, 6(4), 556-568.

predicting GNP per capita. In this direction, the regression model of the research was tried. The data of the study showed that according to the three-stage theoretical model developed, the variables of " the mean years of Schooling, Educational Expenditure, and population growth rate" are predictors of the size of GNP per capita. Most of the studies in the literature reveal findings of similarly classified countries. The determination that " the mean years of schooling" variable among education indicators has a great impact on GNP makes a significant contribution to literature and practice in particular. In countries with different development indices, the sharp findings on education indicators indicate the reasons for the economic power gap and a vision for a solution.

\subsection{Recommendations}

Our results indicate a strong relationship between educational indicators; mean years of schooling, literacy rate, educational expenditure, and population growth rate with the rate of personal economic return (GNP per capita). Especially in underdeveloped and developing states, educational policies are needed to increase educational levels. We offered some policy recommendations based on analysis and results from the study. Institutional policies need to be transparent and clear. In underdeveloped countries, including Niger, education levels can be improved by increasing the shares and resources allocated for education and making good use of them. The adult learning services should be improved for the low literacy rates. In this situation, the nonformal education centers, such as traditional educational institutions, should be allocated sufficient resources.

Our study provides evidence that policymakers can take into consideration. Education rates, literacy rates, and mean years of schooling in underdeveloped countries such as Niger have very low levels compared to Turkey and France. The main reason for this situation can be said to be that there is no concept of a compulsory education period for children, and the length is not regulated. Girls' schooling levels and rural schooling rates are low. The stronger educational' laws encourage that individuals access and continue schooling. Government administrators and policy makers can use our evidence in support of educational laws to ensure better outcomes for the society. For this purpose, national ministries of education should make some incentives or campaigns in rural areas, particularly for the participation of girls in schools, and monitor the introduction of compulsory duration of education in order to increase the schooling rate.

Policymakers also need to allocate resources so that they will be able to prevent or eradicate discrimination in economic incentives based on geography, ethnicity, gender, or age. Since the language of instruction in Niger's schools is French, the number of student dropouts is high. To avoid this, mother tongue or bilingual education can be given at primary school level in Niger. In Turkey, as a developing country, education should be strengthened by allocating more resources and using those resources at the appropriate educational level. This ensures that the standard of the education can be established in practice.

\section{References}

Altunay, E. (2017). Okul Yöneticilerinin Görüşleri Doğrultusunda Eğitim Finansmanı Politikaları: Sorunlar, Nedenler ve Çözümler. Bartın Üniversitesi Eğitim Fakültesi Dergisi. 6(2), 689-714. ISSN: 13087177 . http://dergipark.gov.tr/download/article-file/312868 (g.1.6)

Avcı, S. (2015).Türkiye' de demografik yapı ve eğitim politikaları ilişkisi. Türkiye'de Eğitim Politikaları içinde. Ed. Arife Gümüş. İlem Kitaplığı Ankara: Nobel Yayın.

Aydın, A. (2015). Eğitim Politikası. Geliştirilmiş 2. Baskı. Ankara: Pegem Yayınevi.

Copyright (C) by International Journal of Social Sciences and Education Research 
Djibril Issoufou, M.B., Altunay, E. (2020). The relationship between levels of personal economic returns and education indicators. International Journal of Social Sciences and Education Research, 6(4), 556-568.

Barro, R. J., and Lee, J. W. (1993). International comparisons of educational attainment. Journal of Monetary Economics, 32 (3), 363-394.

Bennet, W.S. Jr. (1967). Educational change and economic development. Sociology of Education. 40 (2), 101114. https://doi.org/10.2307/2112039

Becker, G.S. (1975). Human capital: a theoretical and empirical analysis with special reference to education, 2nd edn. New York: Columbia University Press.

Blankenau, W. F., and Simpson, N. B. (2004). Public education expenditures and growth. Journal of Development Economics, 73(2), 583-605.

Boarini, R., and Strauss, H. (2007). The Private internal rates of return to tertiary education: new estimates for 21 OECD countries. OECD Economics Department Working Papers, No. 591. OECD Publishing $(\mathrm{Nj} 1), 1-63$.

Bowen, G.A. (2009). Document Analysis as a Qualitative Research Method. Qualitative Research Journal, $9(2), 27-40$

Bowman, M. J., and Anderson, C. A. (1961).Concerning the Role of Education in Development. Comparative Education Center, University of Chicago

Büyükarslan, A. M. (1995). Toplumsal Kalkınma ve Eğitim. Kuram ve Uygulamada Eğitim Yönetimi Dergisi, 1(4), 535-544.

Curle, A (1964). Education, politics and development. Comparative Education Review. 226-45.

Çalışkan, Ş. (2007). Eğitimin getirisi (Uşak İli Örneği). Süleyman Demirel Üniversitesi İktisadi ve İdari Bilimler Fakültesi Dergisi, 12( 2), 235-252.

Çetin, B. (2014). Eğitim ve Kalkınma İlişkisi: Türkiye Örneği. Yayınlanmamış Yüksek Lisans Tezi. Karaman: Karamanoğlu Mehmetbey Üniversitesi Sosyal Bilimler Enstitüsü.

Dao, M. Q. (2012). Population and Economic Growth in Developing Countries. International Journal of Academic Research in Business and Social Sciences, 2(1), 6-17.

Desai, V. S. (2012). Importance of literacy in India's economic growth.International Journal of Economic Researcher. 3 (2), 112-124.

Doğrul, N, A (2008). Türkiye'de eğitim harcamalarının ekonomik büyüme üzerine etkileri. Yayınlanmamış Doktora Tezi. Dumlupınar Üniversitesi Sosyal Bilimler Enstitüsü. Kütahya.

Ergen, H. (1999). Türkiye'de eğitimin ekonomik büyümeye etkisi. Ekonomik Yaklaşım Dergisi, 10 (35), 21-52.

Geyikdağı, Y. (1976). Türkiye'de eğitim yatırımları ile gayri safi milli hasıla arasındaki ilişki.Eğitim ve Bilim, 1 (1), 21-33.

Gomez-Castellanos, L., and Psacharopoulos, G. (1990). Earnings and education in ecuador: evidence from the 1987 household survey. Economics of Education Review, 9(3), 219-227.

Gölpek, F. (2012). Eğitim getirilerinin özel ve sosyal açıdan incelenmesi. Afyon Kocatepe Üniversitesi IIIBF Dergisi, 14 (1), 43-53.

Gövdeli, T. (2016). Türkiye'de eğitim-ekonomik büyüme ilişkisi: yapısal kırılmalı birim kök ve eşbütünleşme analizi. Ömer Halisdemir Üniversitesi İktisadi ve İdari Bilimler Fakültesi Dergisi, 9/3, 223-238.

Güneş, S. (2005). Türkiye'de nüfus artışının ekonomik büyümeyle ilişkisi üzerine ekonomik bir analiz. Ankara Üniversitesi SBF Dergisi, 60, 03.

Gylfason, T. and Zoega, G. (2003). Education, social equality and economic growth: a view of the landscape. Cesifo Economic Studies, 49, 557-579.

Haider Bhatti, S., Bourdon, J. and Aslam, M. (2013). Economic returns to education in France: ols and instrumental variable estimations. The Lahore Journal of Economics 18(2), 51-63.

Harbison, F. H., and Myers, C. A. (1964). Education, manpower, and economic growth: strategies of human resource development. Tata Mcgraw-Hill Education. 
Djibril Issoufou, M.B., Altunay, E. (2020). The relationship between levels of personal economic returns and education indicators. International Journal of Social Sciences and Education Research, 6(4), 556-568.

Hodder, I. (2002). TheInterpretation of DocumentsandMaterialCulture. In D. Weinberg (Eds.). QualitativeResearchMethods. (s. 266-279). Oxford: Blackwell Publications.

Idrees, A. S., and Siddiqi, M. W. (2013). Does public education expenditure cause economic growth? Comparison of Developed and Developing Countries. Pakistan Journal of Commerce and Social Sciences, $17,174-183$.

İNSEE (2015). https://www.insee.fr/fr/accueil, Erişim tarihi: 11 Mayss 20176

İNS (2015). http://www.stat-niger.org/statistique/index.php, Retriewed 11 Nisan 2017

Kandır, E. D., (2013). Gelişmekte olan ülkelerde demografik geçiş ve yoksulluk ilişkisi, Yüksek Lisans Tezi, Çukurova Üniversitesi, Adana

Karip, E. (2002). Eğitim, ögrretim ve öğretmenlik mesleği, Yüksel, Ö. (Ed): Öğretmenlik Mesleğine Giriş, Ankara: Pegem A Yayınları.

Kelley, A. C. (1988). Economic consequences of population change in the third world. Journal of Economic Literature, 26(4), 1685-1728.

Kızılkaya, O., ve Koçak, E. (2014). Kamu eğitim harcamaları ve ekonomik büyüme ilişkisi: seçilmiş OECD ülkeleri üzerine bir panel veri analizi. Ekonomi Bilimleri Dergisi, 6 (1), 17-32.

Kugler, B., and Psacharopoulos, G. (1989). Earnings and education in Argentina: An analysis of the 1985 Buenos Aires household survey. Economics of Education Review, 8 (4), 353-365.

Kurul, N. (2012). Eğitim finansmanı. Gözden Geçirilmiş ve Genişletilmiş 2. Baskı. Ankara: Siyasal Kitabevi.

Mincer, J. A. (1974). Schooling and earnings. In Schooling, Experience, and Earnings. Nber. 41-63

OECD (2001). The Well-Being of Nations: The Role of Human and Social Capital, Paris:

Centre for Educational Research and Innovation. https://stats.oecd.org/Idex.aspx?DataSetCode $=$ POP_FIVE_HIST)

OECD (2013). Education at a Glance, OECD yayınları.

Öztürk, N. (2005). İktisadi kalkınmada eğitimin rolü. Sosyo Ekonomi Dergisi, 1 (1), 27-44.

Polat, S. (2010). Ülkelerin Eğitim Sistemi Performanslarının Çok Kriterli Karar Analizi Teknikleri ile Değerlendirilmesi. Yayınlanmamış Yüksek Lisans Tezi. Ankara: Hacettepe Üniversitesi Sosyal Bilimler Enstitüsü.

Psacharopoulos, G. (1985). Returns to education: a further international update and implications. Journal of Human Resources, 91-119.

Psacharopoulos, G. and Woodhall, M. (1985). Returns to education: a further international update and implications. Journal of Human Resources, 583-604.

Psacharopoulos, G. and Patrinos, H. A. (2004). Returns to investment in education: a further update. Education Economics, 12(2), 111-134.

Psacharopoulos, G., ve Chu Ng, Y. (1994). Earnings and Education in Latin America. Education Economics, 2(2), 187-207.

Rahman, S. M. (2011). Relationship among GDP, per capita GDP, literacy rate, and unemployment rate. In Proceedings: 11th Islamic Countries Conference On Statistical Sciences. 21 (1), 103-111.

Sellar, S., \& Lingard, B. (2013). The OECD and the expansion of PISA: New global modes of governance in education. British Educational Research Journal, 40, 6.

Sarı, R. (2002). Kazançlar ve eğitim iliskisi: il bazinda yeni veri tabani ile kanit1. METU Studies in Development, 29 (2), 367.

Sarsılmaz, M. (2003). Nüfus ve ekonomik gelişme ilişkisi: Türkiye Örneği (1938-1999). Yayınlanmamış Yüksek Lisans Tezi. Karadeniz Teknik Üniversitesi Sosyal Bilimler Enstitüsü. Trabzon

Schultz, T. P. (1992). The role of education and human capital in economic development: an empirical assessment (No. 670). Center Discussion Paper. 
Djibril Issoufou, M.B., Altunay, E. (2020). The relationship between levels of personal economic returns and education indicators. International Journal of Social Sciences and Education Research, 6(4), 556-568.

Stevens, P., and Weale, M. (2004). Education and economic growth. International Handbook on the Economics of Education.

Tabachnick, B. G. \& Fidell, L. S. (2007). Using Multivariate Statistics. 5th edition. Boston, MA: Ally and Bacon.

Tansel, A. (1994). Wage employment, earnings and returns to schooling for men and women in Turkey. Economics of Education Review, 13 (4), 305-320.

Tansel, A. (2008). Changing returns to education for men and women in a developing country: Turkey, 1994-2005. In ESPE Conference, 18-21.

Tansel, A., and Daoud, Y. (2014). Returns to education in Palestine and Turkey: A comparative analysis. Perspectives on Global Development and Technology, 13 (3), 347 -378.

Taş, U. (2007). Türkiye'de kalkınma planları ışığında eğitimin kalkınmadaki rolü. Yayınlanmış Yüksek Lisans Tezi. Osmangazi Üniversitesi, Sosyal Bilimler Enstitüsü. Eskişehir.

Telatar, O. M., ve Terzi, H. (2010). Nüfus ve eğitimin ekonomik büyümeye etkisi: Türkiye üzerine bir inceleme. Atatürk Üniversitesi İktisadi ve İdari Bilimler Dergisi, 24 (2), 197-214.

TUIK (2016). http://www.tuik.gov.tr/Start.do. Retriewed 11 Nisan 2017.

Ulusoy, B. (2013). Ailelerin ilköğretim düzeyinde yapmış oldukları hane halkn eğitim harcamaları. Yayınlanmamış Yüksek Lisans Tezi. Kastamonu Üniversitesi Sosyal Bilimler Enstitüsü. Kastamonu.

UIS-UNESCO (2016), http://data.uis.unesco.org/Index.aspx?queryid=242, Retriewed 11 Aralık 2016

UNDP (2010), http://hdr.undp.org/en/content/mean-years-schooling-females-aged-25-years- andabove-years, Retriewed 11 Aralık 2016

Wigley, A. A. ve Akkoyunlu, B. (2011). Türkiye'de eğitimin değerinin ölçülmesi. Hacettepe Üniversitesi Eğitim Fakültesi Dergisi, 40 (40), 375-385.

Woodhall, M (1974). The investment approach to educational planning. No. 32 The Fundamentals of Educational Planning: Lecture-Discussion Series. Unesco: International Institute For Educational Planning. Paris. http://unesdoc.unesco.org/images/0006/000692/069263eo.pdf

World Bank (2016), http://databank.worldbank.org/data/download/GDP.pdf. Retriewed 05 Nisan 2017 